Article

\title{
Effect of Spirulina platensis Biomass with High Polysaccharides Content on Quality Attributes of Common Carp (Cyprinus carpio) and Common Barbel (Barbus barbus) Fish Burgers
}

\author{
Mohamed Barkallah ${ }^{1}$, Ali Ben Atitallah ${ }^{1}$, Faiez Hentati ${ }^{1,2}{ }^{2}$, Mouna Dammak ${ }^{1}$, Bilel Hadrich ${ }^{1}$ (), \\ Imen Fendri ${ }^{3}$, Mohamed Ali Ayadi ${ }^{4}$, Philippe Michaud ${ }^{2}$ (D) and Slim Abdelkafi ${ }^{1, *(D)}$ \\ 1 Unité de Biotechnologie des Algues, Biological Engineering Department, National Engineering School of \\ Sfax, University of Sfax, Sfax 3038, Tunisia; mohamedbarkallah@gmail.com (M.B.); atitali@yahoo.fr (A.B.A.); \\ faizhentati@gmail.com (F.H.); dammakmouna23@yahoo.fr (M.D.); bilelhadrich@yahoo.fr (B.H.) \\ 2 Université Clermont Auvergne, CNRS, Institut Pascal, Polytech Clermont Ferrand, 2 avenue Blaise Pascal, \\ 63178 Aubière, France; philippe.michaud@uca.fr \\ 3 Laboratory of Plant Biotechnology Applied to the Improvement of Cultures, Faculty of Sciences of Sfax, \\ B.P. 1171, 3000, University of Sfax, Sfax 3029, Tunisia; imen.fendri@fss.usf.tn \\ 4 Laboratory of Analysis Valorization and Food Safety, National Engineering School of Sfax, University of Sfax, \\ Sfax 3038, Tunisia; ayadimedali@gmail.com \\ * Correspondence: slim.abdelkafi@enis.tn; Tel.: +216-97-458-923
}

Received: 5 May 2019; Accepted: 27 May 2019; Published: 29 May 2019

check for updates

\begin{abstract}
Lately, microalgae have been used as natural additives in fish-transformed products to improve their nutritional quality. In this research, the effects of adding Spirulina platensis at concentrations of $0.5,1$ and $1.5 \% w / v$ on both the texture and the sensory characteristics of canned burgers were studied. In fact, the addition of Spirulina platensis to fish burgers improves their nutritional composition. Compared to the results of the other fish burger treatments, the treatments that contain $1 \%$ of Spirulina platensis had better texture and sensory properties $(p<0.05)$. Besides, these treatments showed higher swelling ability as well as water and oil holding capacities, due to the important dietary fibers and polysaccharides contents found in Spirulina platensis. No mold or foodborne pathogens were detected in any of the canned burgers up to 8 months of storage at $4{ }^{\circ} \mathrm{C}$. Furthermore, burgers prepared with Spirulina were distinguished by the lowest mean $\left(\mathrm{a}^{*}\right.$ and $\left.\mathrm{b}^{*}\right)$ values $(p<0.05)$, which shows that the yellow color gradually diminished towards a greenish color. Because of the presence of polysaccharides and pigments (chlorophylls, carotenoids and phycocyanin), Spirulina platensis considerably ameliorates the antioxidant activities of the newly prepared fish burgers. On the whole, we can conclude that Spirulina platensis can be used as a nutritious additive to produce new fish-based products with high alimentary qualities.
\end{abstract}

Keywords: Canned fish burgers; Spirulina platensis; texture; polysaccharides; carotenoids; antioxidant activities

\section{Introduction}

Compared to many other food types such as meat, poultry and dairy products, fish is highly nutritious, delicious and easily digested. It has an excellent nutritional value. It provides high quality proteins and a wide variety of vitamins such as vitamins A and D and minerals including phosphorus, magnesium, selenium and iodine [1]. Not only its protein is easily digestible but also it favorably complements the dietary protein provided by cereals and legumes that are typically consumed in many developing countries [2]. Currently, the consumption of fish-based products is gradually rising 
due to increasing consumer concerns about health problems. In 2013, fish accounted for $6.7 \%$ of all protein consumed and for $17 \%$ of the equivalent global figure [2]. The overexploitation of most valuable fish stocks has contributed to an imbalance in supply and demand of fishery products in several countries [3]. As a result, the idea of exploiting freshwater fish species (Nile tilapia, common carp and common barbel) in intensive farming has appeared.

The common carp (Cyprinus carpio) and the common barbel (Barbus barbus), are two species of freshwater fish that belong to the family of Cyprinidae [4,5]. Their flesh is characterized by a beneficial nutritional composition of indispensable amino acids, high omega- 3 and -6 polyunsaturated fatty acids contents, certain minerals, fat and water-soluble vitamins [6] and low levels of cholesterol and saturated fats [1]. The presence of many intramuscular bones in their flesh is the cause of their low consumption by Tunisians. Hence, it is very important to produce new fish-based products from these underused fish species in the field of fish processing through various transformation methods to make them useful and savory aliments for a human diet. In recent years, the consumer preferences have been considerably directed towards the consumption of ready-to-eat fish products, since there has been a rapid process of urbanization and a rapid increase in the working population in most countries. One of the most popular mince-based products is fish burger. It is highly consumed, principally due to the increase in the number of fast foods available worldwide, as well as its convenience and low price [7]. To the best of our knowledge, in the literature there aren't many studies concerning fish-based products and very little information about the potential use of flesh from common carp and common barbel in manufacturing fish burgers.

Despite their health benefits, fish burgers are not generally considered as a major source of bioactive compounds (e.g., polysaccharides, carotenoids, essential oils, antioxidants and flavors) [1]. During recent years, nutritionists have mentioned that the fortification of fish-based food products using functional ingredients and supplements is an optimal way to ameliorate the total food intake. Meanwhile, the fish burger has continued to draw the attention of consumers because it's both healthy and tasty. In the agri-food industries, divers' synthetic additives have been used for the sake of coloring, flavoring, fortifying and extending the shelf-life of the commercialized products [7]. Still, many recent scientific studies have shown that an excessive consumption of synthetic food supplements is linked to many health problems [8]. Thus, the need to use natural food fortifiers has pushed experts to prepare additives from natural resources that might be suitable in the production of fish-products [7].

Recently, microalgae have attracted attention in the food industry and the principal genera used for functional foods are Chlorella, Dunaliella and Spirulina. Spirulina platensis is a cyanobacterium with a special composition of nutritional and bioactive substances (e.g., proteins, vitamins, minerals, pigments and phenolic acids) and with a large range of medical applications [9]. This cyanobacterium contains a very potent naturally occurring antioxidant and free radical scavenging agents such as pigments (phycocyanin and Beta-carotene) [10] and polysaccharides [11], that are well-known products to protect against various diseases, such as renal failure [12], hypertension [13] and cancers [11,14]. Besides their antioxidant effects, pigments and polysaccharides of Spirulina platensis have been found to show antibacterial and antiviral activities $[15,16]$.

The principal objectives of this study are first to produce new canned fish burgers prepared from common carp and common barbel fortified with Spirulina, and second to assess the effects of Spirulina on the sensorial, microbiological, functional and textural characteristics of these products.

\section{Material and Methods}

\subsection{Collection of Fish}

Fish (common carp and common barbel) were caught from the reservoir of Sidi Salem in January 2017. Then, they were directly transferred in polyethylene bags to the pilot unit of fish processing of Tabarka (Governorate of Jendouba, Tunisia), where they were tested for their freshness and processed 
(washed, beheaded, gutted and fileted). Next, the skinless fish filets were minced in a blender (Robot Coupe USA Inc., Ridgeland, MS, USA) and kept at $-20^{\circ} \mathrm{C}$ for $48 \mathrm{~h}$.

\subsection{Fish Burger Manufacture}

Fish burgers were manufactured using a commercial burger maker (Model Hamburger MV NEW, Food Tech S.r.l.,-Bologna, Italy), after being thawed and chopped to a diameter of about $10 \mathrm{~mm}$, mixed thoroughly with salt $(2 \% w / v)$, starch $(1 \% w / v)$, and different concentrations $(0.5,1$ and $1.5 \%)$ of Spirulina powder (Bio Algues, Mahdia, Tunisia) and transformed into disc burgers that were $6 \mathrm{~cm}$ wide, 1.5 $\mathrm{cm}$ thick and that weighed $100 \mathrm{~g}$. The obtained burgers were soaked in sunflower oil $(20 \mathrm{~mL})$ and individually placed in RO-100 cans $(6.52 \mathrm{~cm}$ diameter, $3 \mathrm{~cm}$ height) using a seamer machine (Seamer Semiautomatica, MOD.AGM, S. Bologna, Italy). The canned burgers were then cooked at $120^{\circ} \mathrm{C}$ for $40 \mathrm{~min}$ using a retort. After cooling, cans were stored at $4{ }^{\circ} \mathrm{C}$ in a refrigerator for further analysis (8 months). Spirulina-free burgers were used as controls.

\subsection{Physicochemical Properties of Fish Burger}

A pH meter (Metrohm-744 pH meter, Heirisau, Switzerland) was calibrated with standard buffer solutions and used to measure the $\mathrm{pH}$ of Spirulina-fortified and unfortified fish burgers. Their water activity $\left(\mathrm{a}_{\mathrm{w}}\right)$ was determined using a Novasina Thermoconstanter SPRINT TH500 (Axair Ltd., Pfäffikon, Switzerland) at $25^{\circ} \mathrm{C}$. The equipment was previously calibrated using the calibration procedure of the equipment manufacturer, using the salts: $\mathrm{MgCl}_{2}, \mathrm{NaCl}, \mathrm{BaCl}_{2}$ and $\mathrm{K}_{2} \mathrm{Cr}_{2} \mathrm{O}_{7}$ (Sigma-Aldrich, St. Louis, MO, USA). All measurements were carried out in triplicate.

The infra-red absorption spectra of all burger formulations were obtained using the Cary 630 FTIR spectrometer (Agilent Technologies., Santa Clara, CA, USA) as described by Ben Atitallah et al. [17]. The acquisition and the processing of spectra were carried out using the Agilent MicroLab PC software v.5.3 (Agilent Technologies Inc.).

Total solids (TS) and Ash contents were determined as described by Ben Atitallah et al. [17]. The content of protein was estimated using the classical Kjeldhal procedure of the AOAC International (method 981.10) with a nitrogen conversion factor of 6.25 [18]. Total lipids were extracted using the modified procedure of Bligh and Dyer [19] and measured as described by Fendri et al. [20]. The determination of total dietary fibers in burger samples was done according to the method described by Barkallah et al. [21]. Contents of chlorophylls and carotenoids were estimated as described by Lichtenthaler and Wellburn [22] and Kumar et al. [23]. The determination of c-phycocyanin was done according to the protocol described by Bennet and Bogorad [24].

\subsection{Functional Properties of Fish Burger}

The swelling capacity (SWC) of powdered fish burgers was determined as described by Kuniak and Marchessault [25]. The SWC was expressed as $\mathrm{mL}$ of swollen sample/g dry weight (mL/g dw). All measurements were carried out in duplicates.

The water holding capacity (WHC) of powdered fish burgers was determined as described by Okezie and Bello [26]. The sample was weighed immediately and the WHC of burger samples was expressed as g water/g dw. All analyses were done in duplicates.

The oil holding capacity (OHC) of powdered burgers was determined as described by Wong and Cheung [27]. The OHC of burger samples was expressed as $g$ of oil held/g of sample (g/g dw).

\subsection{Sensory Evaluation}

The attributes of fish burgers were evaluated by 20 female and 10 male panelists aged from 20 to 45 years. The tasting panel included researchers and employees in the pilot unit of fish processing of Tabarka. Burger samples were distributed on white polystyrene plates and shown to the panelists with three digit codes in a random order. Experiments were done in a sensory evaluation room equipped with white light and controlled ventilation; water was served for the purpose of cleaning the mouth 
between samples. Panel members evaluated the burgers for taste, body and texture, color, appearance and odor based on a traditional 5 point-hedonic scale $(1=$ very bad, $2=$ bad, $3=$ neither bad nor good, $4=$ good and $5=$ very good) for each parameter [17]. A score of 4 will be considered the threshold for acceptance of the fish burger.

\subsection{Color Analysis}

The color evaluation of unfortified and Spirulina-fortified fish burgers was done using a spectro-colorimeter (Konica Minolta, Chroma Meter, CR400, Japan), calibrated with white and black ceramic plates. An average color value was measured by taking measurements from different points (Two on the top and three on the bottom) of the same sample, and the L*a*b* color space values were noted [17].

\subsection{Textural Analysis}

All instrumental texture analyses were carried out on fish burger formulations stored at 4 ${ }^{\circ} \mathrm{C}$ for $24 \mathrm{~h}$, using a professional texture analyzer with blade probe (Texture Analyser, TA Plus, LLOYD instruments, England). Texture parameters were determined and interpreted as described by Bourne [28].

\subsection{Antioxidant Properties Evaluation Using DPPH and FRAP Methods}

The free radical scavenging activity of fish burger samples was estimated using the DPPH (1,1-diphenyl-2-picryl-hydrazil) method of Bersuder et al. [29]. The ferric reducing antioxidant power (FRAP) of fish burgers was determined as described by Yildrim et al. [30]. All antioxidant reactions were done in triplicates.

\subsection{Microbiological Analyses}

The microbiological analyses of fish burgers were done throughout the storage period (8 months). The tests for Escherichia coli, Enterobacteriaceae, mold, yeast, coliforms and foodborne pathogens (Salmonella spp., Shigella spp., Listeria monocytogenes, Bacillus cereus and Staphylococcus aureus) were done using the standard microbiological methods for the analysis of ready-to-eat foods [31,32]. After enrichment, burger samples were plated onto polymyxin—acriflavine-lithium chloride—ceftazidime—aesculin—mannitol (PALCAM) agar (Conda, Madrid, Spain), Baird Parker agar (Oxoid Ltd., Basingstoke, UK) and Salmonella-Shigella (SS) agar (Conda) for the detection of Listeria monocytogenes, Staphylococcus aureus and Salmonella-Shigella, respectively. Three presumptive colonies from each plate were selected for biochemical characterization [30]. Biochemical tests used to confirm Staphylococcus aureus were the coagulase test, catalase test, indole production, methyl red test, Voges-Proskauer reaction, urease production, citrate utilization and sugar fermentation. Listeria monocytogenes, Salmonella and Shigella colonies were biochemically characterized using API Listeria and API 20E test kits (BioMerieux Inc., Lyon, France), respectively. The burgers were also tested for the presence of coliforms and Escherichia coli using the most probable number (MPN) method [31]. Mold and yeasts were detected and enumerated by diluting $1 \mathrm{~g}$ of burger sample in $9 \mathrm{~mL}$ of $0.1 \%$ peptone water (Conda), followed by two min of homogenization at $2000 \mathrm{rpm}$ using the hand-held homogenizer. Subsequently, serial dilutions were made using $0.1 \%$ peptone water and then samples were plated, using potato dextrose agar (Conda) acidified to $\mathrm{pH} 3.5$ with $10 \%$ tartaric acid solution. All plates were then incubated at $25^{\circ} \mathrm{C}$ and colonies were counted after 3 days. The results were expressed as $\mathrm{CFU} / \mathrm{g}$ [17].

\subsection{Statistical Analysis}

Analytical determinations were done at least in duplicates and obtained values were expressed as the mean and standard deviation (SD). Comparison of means of values among different treatments was 
effectuated using a One-way ANOVA test followed by using post hoc Duncan's Multiple Range Tests (DMRT) ( $p$ values $<0.05$ were considered to be statistically significant). IBM SPSS software package version 19.0 (IBM Corp., USA) was used for this purpose.

\section{Results and Discussion}

\subsection{Preliminary Results}

The taste, after-taste, odor, color, texture and overall acceptability of the canned fish burgers were evaluated. Results are shown in Table 1. In general, the hedonic results showed better scores for carp and barbel burgers enriched with 0.5 and $1 \%(w / v)$ of Spirulina. Statistically, formulations with the highest Spirulina concentration $(1.5 \%)$ possessed inferior sensory acceptability for the majority of the organoleptic characteristics compared to formulations with the lower Spirulina concentrations $(p<0.05)$ and controls $(p<0.05)$ (Table 1). The inappropriate taste caused by the supplementation of high concentration of Spirulina is related to the obtained compounds from the lipid oxidation and to the minerals that not only operate as pro-oxidant molecules but also might produce undesirable metallic off-flavors [33]. Yet, taste scores of carp and barbel burgers formulated with 0.5 and $1 \%$ of Spirulina were similar to control fish burgers $(p>0.05)$ (Table 1). The microalga addition modified the color of carp and barbel burgers from yellowish white to green, depending on the added concentration of microalga. This characteristic was considered by panelists as an inappropriate sensory feature (color appearance) $(p<0.05)$. The decrease in color pleasantness might be explained by the fact that batches rich in Spirulina showed an increase in the green color as the amount of chlorophylls increased, which results in a color very different from that expected in a control fish burger. In the case of mouth-texture, some panel members declared that the burger texture was ameliorated by increasing the percentage of Spirulina; however, these differences were significant $(p<0.05)$ compared to controls only for carp formulations (Table 1).

Table 1. Mean scores of tasting panelists $(n=30)$ for sensory properties of control and fortified burgers with different percentage $(0.5,1$ and $1.5 \%)$ of Spirulina.

\begin{tabular}{|c|c|c|c|c|c|}
\hline \multirow[t]{2}{*}{ Sensory Properties } & \multirow{2}{*}{$\begin{array}{c}\text { Fish Burger } \\
\text { Types }\end{array}$} & \multicolumn{4}{|c|}{ Formulations } \\
\hline & & Control burger & $\begin{array}{l}0.5 \% \text { Spirulina } \\
\text { fish burger }\end{array}$ & $\begin{array}{l}1 \% \text { Spirulina } \\
\text { fish burger }\end{array}$ & $\begin{array}{l}1.5 \% \text { Spirulina } \\
\text { fish burger }\end{array}$ \\
\hline \multirow{2}{*}{ Taste } & $\mathrm{CB}$ & $4.42 \pm 0.05$ & $4.48 \pm 0.145$ & $4.26 \pm 0.179$ & $3.98 \pm 0.034 \mathrm{bfg}$ \\
\hline & BB & $4.12 \pm 0.53$ & $4.03 \pm 0.42$ & $3.98 \pm 0.296$ & $3.02 \pm 0.203^{c e h}$ \\
\hline \multirow{2}{*}{ After-taste } & $\mathrm{CB}$ & $4.35 \pm 0.296$ & $4.13 \pm 0.014$ & $4.11 \pm 0.015$ & $3.99 \pm 0.020^{a}$ \\
\hline & $\mathrm{BB}$ & $4.08 \pm 0.251$ & $4.10 \pm 0.428$ & $4.07 \pm 0.381$ & $3.39 \pm 0.307^{\mathrm{ad} \mathrm{g}}$ \\
\hline \multirow{2}{*}{ Odor } & $\mathrm{CB}$ & $3.99 \pm 0.021$ & $4.03 \pm 0.024$ & $4.04 \pm 0.050$ & $4.02 \pm 0.017$ \\
\hline & $\mathrm{BB}$ & $4.01 \pm 0.283$ & $4.00 \pm 0.261$ & $4.01 \pm 0.312$ & $4.05 \pm 0.311$ \\
\hline \multirow{2}{*}{ Color } & $\mathrm{CB}$ & $4.26 \pm 0.08$ & $4.29 \pm 0.06$ & $4.15 \pm 0.07$ & $3.91 \pm 0.08^{\mathrm{cfh}}$ \\
\hline & $\mathrm{BB}$ & $4.01 \pm 0.432$ & $4.02 \pm 0.419$ & $4.02 \pm 0.521$ & $3.88 \pm 0.489$ \\
\hline \multirow{2}{*}{ Mouth-texture } & $\mathrm{CB}$ & $4.03 \pm 0.090$ & $4.09 \pm 0.060$ & $4.24 \pm 0.050^{b d}$ & $4.17 \pm 0.022^{\mathrm{a}}$ \\
\hline & BB & $3.98 \pm 0.123$ & $4.09 \pm 0.327$ & $4.02 \pm 0.222$ & $4.01 \pm 0.284$ \\
\hline \multirow{2}{*}{ Overall-acceptability } & $\mathrm{CB}$ & $4.12 \pm 0.032$ & $4.12 \pm 0.020$ & $4.13 \pm 0.034$ & $4.03 \pm 0.023 \mathrm{~b} \mathrm{e} \mathrm{h}$ \\
\hline & $\mathrm{BB}$ & $4.12 \pm 0.156$ & $4.11 \pm 0.238$ & $4.08 \pm 0.145$ & $3.80 \pm 0.05^{\mathrm{a} \mathrm{d} g}$ \\
\hline
\end{tabular}

CB: carp burgers; BB: barbel burgers; Control vs. fortified burgers $(0.5 \%, 1 \%$ and $1.5 \%):{ }^{a} p<0.05 ;{ }^{b} p<0.01$; ${ }^{\mathrm{c}} p<0.001 ; 0.5 \%$ Spirulina burgers vs. 1 and $1.5 \%$ Spirulina burgers: ${ }^{\mathrm{d}} p<0.05 ;{ }^{\mathrm{e}} p<0.01 ;{ }^{\mathrm{f}} p<0.001 ; 1 \%$ Spirulina burgers vs. $1.5 \%$ Spirulina burgers: ${ }^{\mathrm{g}} p<0.05 ;{ }^{\mathrm{h}} p<0.01$.

Overall, treatments with $1.5 \%$ of Spirulina minimized the sensorial quality of fish burgers, especially from the point of view of taste and after taste. According to these results, it seems that $0.5 \%$ Spirulina 
concentration is the threshold level which has no significant effects on the sensory quality of the fish products; however, panel members were still satisfied with fish burgers containing $1 \%$ added Spirulina. Thus, carp and barbel burgers fortified with 0.5 and $1 \%$ of Spirulina were chosen for further analyses to assess their physicochemical properties.

The Spirulina incorporation into fish burger composition had no significant effect on $\mathrm{pH}$ values (Table 2). Furthermore, the addition of Spirulina (for any concentration) did not modify $(p>0.05)$ the protein and fat contents (Table 2) for the two types of burgers. These contents were confirmed qualitatively with FTIR analysis (Figure 1A,B). The strong absorption in the region of $3200 \mathrm{~cm}^{-1}$ corresponds to the hydroxyl $(\mathrm{O}-\mathrm{H})$ stretching vibration of proteins and residual water. The strong absorption in the region of 3000 and $2800 \mathrm{~cm}^{-1}$ corresponds to the stretching of $\mathrm{NH}_{2}$ groups, which reflects the high protein content in burger samples. The protein spectrum was characterized by the presence of absorption peaks at 1624 and $1522 \mathrm{~cm}^{-1}$ attributed to the $\mathrm{NH}$ and $\mathrm{C}=\mathrm{O}$ groups of amides I (1590-1650 $\left.\mathrm{cm}^{-1}\right)$ and the stretching of $\mathrm{NH}$ groups and asymmetric $\mathrm{N}=\mathrm{O}$ groups of amide II (1500-1560 $\mathrm{cm}^{-1}$ ) [34]. The lipid spectrum was characterized by the presence of absorption peaks at 2922, 2852 and $1742 \mathrm{~cm}^{-1}$ attributed to the stretching of $\operatorname{Vas}\left(\mathrm{CH}_{2}\right), \mathrm{Vs}\left(\mathrm{CH}_{2}\right)$ and $\mathrm{V}(\mathrm{C}=\mathrm{O})$, respectively, while the absorption peak at $1377 \mathrm{~cm}^{-1}$ mainly showed the $\mathrm{C}-\mathrm{O}$ stretching vibrations of carboxylic acids [34]. The absorption peaks found between 950 and $1200 \mathrm{~cm}^{-1}$ represent carbohydrates [17]. Compared to control, Spirulina-fortified samples did not show a significant appearance of specific absorption peaks for the two types of fish burger (Figure 1A,B).

Table 2. Mean values for physicochemical characteristics of control and Spirulina-fortified burgers at one week after production.

\begin{tabular}{|c|c|c|c|c|}
\hline \multirow[t]{2}{*}{$\begin{array}{l}\text { Physicochemical } \\
\text { Characteristics }\end{array}$} & \multirow[t]{2}{*}{$\begin{array}{l}\text { Fish Burger } \\
\text { Types }\end{array}$} & \multicolumn{3}{|c|}{ Burger Formulations } \\
\hline & & Control burger & $\begin{array}{l}0.5 \% \text { Spirulina fish } \\
\text { burger }\end{array}$ & $\begin{array}{c}\text { 1\% Spirulina fish } \\
\text { burger }\end{array}$ \\
\hline \multirow{2}{*}{$\mathrm{pH}$} & $\mathrm{CB}$ & $7.21 \pm 0.07$ & $7.16 \pm 0.01$ & $7.17 \pm 0.01$ \\
\hline & $\mathrm{BB}$ & $7.14 \pm 0.02$ & $7.1 \pm 0.015$ & $7.07 \pm 0.025$ \\
\hline \multirow{2}{*}{ Water activity $\left(a_{w}\right)$} & $\mathrm{CB}$ & $0.982 \pm 0.000$ & $0.979 \pm 0.000^{\mathrm{a}}$ & $0.978 \pm 0.000^{c}$ \\
\hline & $\mathrm{BB}$ & $0.982 \pm 0.001$ & $0.974 \pm 0.000^{c}$ & $0.969 \pm 0.001^{\mathrm{cf}}$ \\
\hline \multirow{2}{*}{ Moisture (\% FW) } & $\mathrm{CB}$ & $77.03 \pm 0.055$ & $76.55 \pm 0.053$ & $76.36 \pm 0.078$ \\
\hline & BB & $77.57 \pm 0.32$ & $77.17 \pm 0.072^{a}$ & $77.00 \pm 0.046^{b}$ \\
\hline \multirow{2}{*}{$\begin{array}{l}\text { Total solids (\% } \\
\text { FW) }\end{array}$} & $\mathrm{CB}$ & $22.96 \pm 0.055$ & $23.44 \pm 0.053^{c}$ & $23.63 \pm 0.078^{\text {ce }}$ \\
\hline & $\mathrm{BB}$ & $22.43 \pm 0.32$ & $22.82 \pm 0.072$ & $23 \pm 0.046^{a}$ \\
\hline \multirow{2}{*}{ Protein (\% DW) } & $\mathrm{CB}$ & $79.66 \pm 0.119$ & $79.50 \pm 0.019$ & $79.20 \pm 0.096$ \\
\hline & $\mathrm{BB}$ & $78.24 \pm 0.125$ & $78.21 \pm 0.070$ & $78.02 \pm 0.012^{a}$ \\
\hline \multirow{2}{*}{ Fat (\% DW) } & $\mathrm{CB}$ & $7.79 \pm 0.15$ & $7.67 \pm 0.04$ & $7.46 \pm 0.068$ \\
\hline & $\mathrm{BB}$ & $8.33 \pm 0.085$ & $8.25 \pm 0.095$ & $8.24 \pm 0.010$ \\
\hline \multirow{2}{*}{ Ash (\% DW) } & $\mathrm{CB}$ & $11.12 \pm 0.105$ & $11.18 \pm 0.013$ & $11.69 \pm 0.046^{c f}$ \\
\hline & BB & $11.53 \pm 0.03$ & $11.56 \pm 0.315$ & $11.84 \pm 0.155^{\mathrm{cf}}$ \\
\hline \multirow{2}{*}{$\begin{array}{l}\text { Total dietary fiber } \\
(\mathrm{g} / 100 \mathrm{~g} \mathrm{DW})\end{array}$} & $\mathrm{CB}$ & $0.32 \pm 0.024$ & $0.5 \pm 0.075^{c}$ & $0.76 \pm 0.024^{c f}$ \\
\hline & $\mathrm{BB}$ & $0.203 \pm 0.000$ & $0.308 \pm 0.016^{\mathrm{a}}$ & $0.817 \pm 0.158^{\mathrm{cf}}$ \\
\hline
\end{tabular}

CB: carp burger; BB: barbel burger; Control vs. fortified burgers $(0.5 \%, 1 \%$ and $1.5 \%)$ : ${ }^{\mathrm{a}} p<0.05$; $^{\mathrm{b}} p<0.01$; $^{\mathrm{c}} p<0.001$; $0.5 \%$ Spirulina burgers vs. 1 and $1.5 \%$ Spirulina burgers: ${ }^{\mathrm{d}} p<0.05 ;{ }^{\mathrm{e}} p<0.01 ;{ }^{\mathrm{f}} p<0.001$; The percentage is calculated relative to a dry weight basis (DW) for lipid, protein, fat and ash whereas the moisture content and total solids are expressed with respect to a fresh weight basis (FW). 

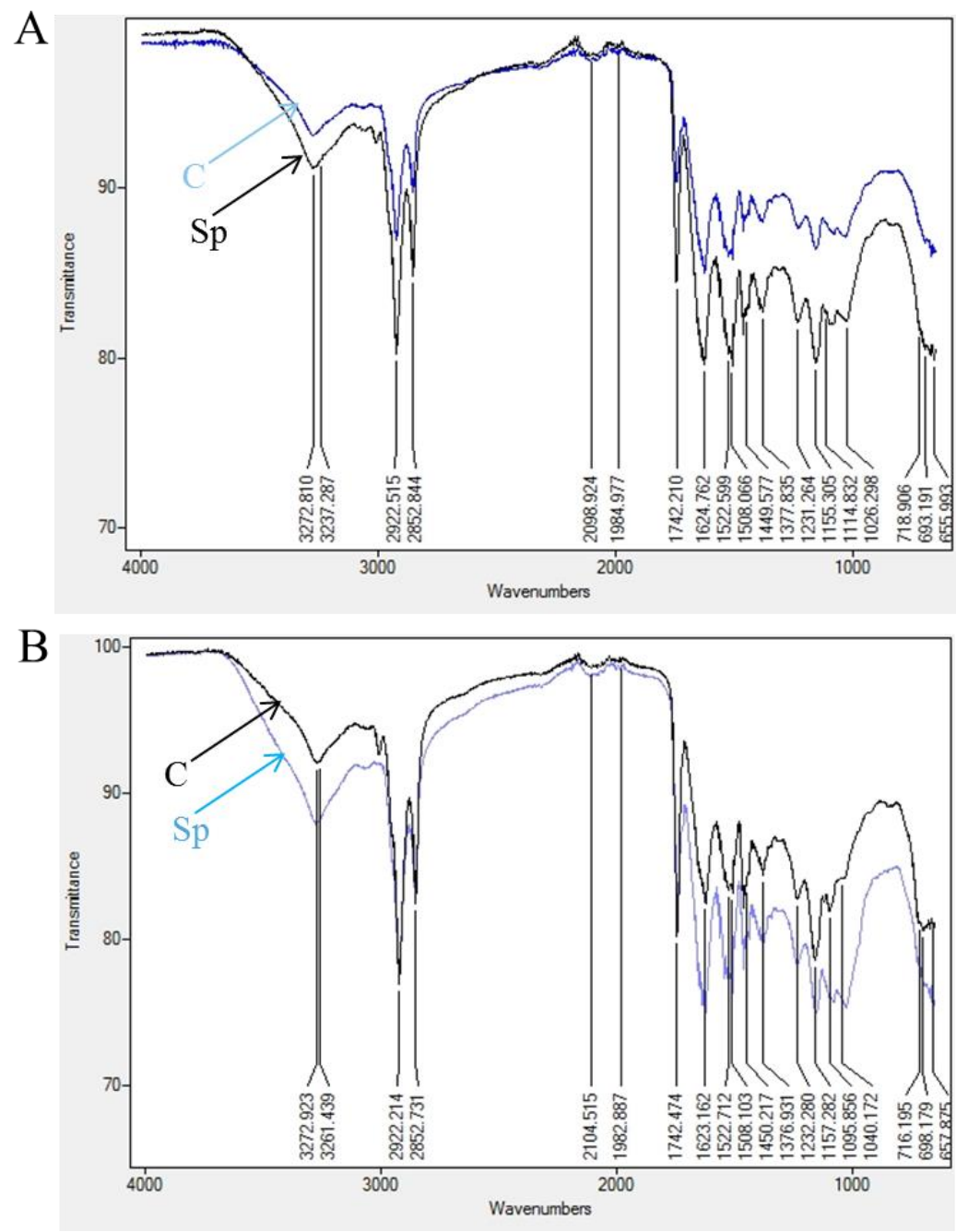

Figure 1. FTIR spectra of control (c) and Spirulina -fortified burgers made from barbel (A) and carp (B).

Nevertheless, total solids (TS), total dietary fibers and ash contents were found to be the highest in carp and barbel burgers fortified with Spirulina $(p<0.05)$ (Table 2). For carp formulations, TS of the control and fortified burgers with 0.5 and $1 \%$ of Spirulina were 22.96, 23.44 and $23.63 \%$, respectively. There was a significant difference in terms of TS between these 3 formulations $(p<0.001)$ (Table 2$)$. This increase was not significant between barbel formulations. Similarly, the dietary fiber values of all Spirulina-fortified burgers were significantly $(p<0.01)$ increased when compared with that of control burgers. This was probably due to the high dietary fiber content of Spirulina. For the two types of fish burger, samples treated with $0.5 \%$ of Spirulina significantly showed $(p<0.001)$ lower values for dietary fibers in comparison to samples treated with $1 \%$ of Spirulina. The high dietary fiber content of fortified burgers might have played an important role in a reduced level of water activity $\left(\mathrm{a}_{\mathrm{w}}\right)$ compared with the control burgers [35]. In addition, Spirulina increased the Ash content of carp and barbel burgers depending on microalga concentration (Table 2). These findings are consistent with previous results that indicated the richness of Spirulina in minerals [21]. Variations in these physicochemical parameters, especially regarding the contents of dietary fibers, may affect certain other functional parameters such as water and oil holding capacities. According to the obtained results, carp and barbel burgers supplemented with $1 \%$ of Spirulina were chosen as the best final products and selected for further analyses to evaluate their textural, functional, microbiological and antioxidant properties. 


\subsection{Textural Parameters}

Actually, textural amendment is one of the most commonly used modes in the evaluation and treatment of swallowing difficulties (dysphagia). It is an essential criterion used to define the organoleptic quality of food products. Table 3 shows the effect of adding $1 \%$ of Spirulina on the textural properties of fish burgers.

Table 3. Parameters obtained using texture analyzer for control and fortified burgers with different concentrations of Spirulina.

\begin{tabular}{cccc}
\hline Textural Parameters & Fish Burger Types & \multicolumn{2}{c}{ Burger Formulations } \\
\hline \multirow{2}{*}{ Hardness (N) } & & Control burger & 1\% Spirulina fish burger \\
\cline { 2 - 4 } & $\mathrm{CB}$ & 8.35 & $13.53^{\mathrm{c}}$ \\
\hline \multirow{2}{*}{ Elasticity (cm) } & $\mathrm{BB}$ & 6.69 & $7.39^{\mathrm{a}}$ \\
\cline { 2 - 4 } & $\mathrm{CB}$ & 0.36 & 0.38 \\
\hline \multirow{2}{*}{ Chewiness (N.cm) } & $\mathrm{BB}$ & 0.56 & $0.85^{\mathrm{c}}$ \\
\cline { 2 - 4 } & $\mathrm{CB}$ & 1.11 & $2.21^{\mathrm{c}}$ \\
\hline \multirow{2}{*}{ Gumminess (N) } & $\mathrm{BB}$ & 0.88 & $2.40^{\mathrm{c}}$ \\
\cline { 2 - 4 } & $\mathrm{CB}$ & 3.09 & $5.84^{\mathrm{c}}$ \\
\hline \multirow{2}{*}{ Cohesion } & $\mathrm{BB}$ & 1.58 & $2.83^{\mathrm{c}}$ \\
\cline { 2 - 4 } & $\mathrm{CB}$ & 0.371 & $0.432^{\mathrm{a}}$ \\
\hline
\end{tabular}

CB: carp burgers; BB: barbel burgers; Control vs. $1 \%$ Spirulina-fortified burgers: ${ }^{\mathrm{a}} p<0.05 ;{ }^{\mathrm{b}} p<0.01 ;^{\mathrm{c}} p<0.001$.

Compared to control burgers made from carp and barbel, the addition of 1\% Spirulina led to an increase in hardness from 8.35 to $13.53 \mathrm{~N}(p<0.001)$ and from 6.69 to $7.39 \mathrm{~N}(p<0.05)$, respectively. This could presumably be attributed to the composition differences between unfortified and Spirulina-fortified burgers, resulting in different protein/fat/water ratios, which are determining elements in the resulting gel consistency [34]. These results are in accordance with reports by Cofrades et al. [36] and Fernandez-Martin et al. [37] in burger patties with added seaweeds. However, Dolea et al. [38] suggested that the hardness was not modified by the addition of thyme and oregano essential oils in salmon and seaweed burgers. Furthermore, fibers and polysaccharides of Spirulina can also play an important role in modifying the hardness of these processed products.

Depending on the amount and type of fibers, controversial results have been reported on the hardness of food products. Thus, both hardening and softening have been observed when fibers were added to various cooked food products $[39,40]$. Chewiness was increased significantly $(p<0.001)$ when the microalga was added (Table 3). These results are in good agreement with the experimental data obtained by Jiménez Muñoz et al. [41]. Cohesiveness values increased when Spirulina was added and statistically significant differences were found between the control and $1 \%$ Spirulina-fortified samples for the two types of fish burger. Cohesiveness results of carp and barbel burgers formulated with $1 \%$ Spirulina were comparable with the values reported by Kumarathunge et al. [42] for catla burgers formulated with $0.5 \%(w / w)$ Ulva lactuca. In industry, the mentioned texture results might be considered satisfactory because Spirulina did not mischaracterize the textural characteristics that were already known and accepted by the panelists.

\subsection{Functional Properties of Fish Burgers}

The functional characteristics of control and Spirulina-fortified burgers are shown in Table 4. 
Table 4. Functional parameters of control and Spirulina-fortified fish burgers.

\begin{tabular}{|c|c|c|c|}
\hline \multirow{2}{*}{$\begin{array}{c}\text { Functional } \\
\text { Characteristics }\end{array}$} & \multirow[t]{2}{*}{ Fish Burger Types } & \multicolumn{2}{|c|}{ Burger Formulations } \\
\hline & & Control burger & $1 \%$ Spirulina fish burger \\
\hline \multirow{2}{*}{$\mathrm{SWC}(\mathrm{mL} / \mathrm{g} \mathrm{DW})$ * } & $\mathrm{CB}$ & $3.13 \pm 0.115$ & $3.56 \pm 0.110^{a}$ \\
\hline & BB & $2.99 \pm 0.03$ & $3.43 \pm 0.02^{a}$ \\
\hline \multirow{2}{*}{ OHC (g/g DW) * } & $\mathrm{CB}$ & $0.85 \pm 0.07$ & $0.90 \pm 0.017^{\mathrm{a}}$ \\
\hline & $\mathrm{BB}$ & $0.86 \pm 0.014$ & $1.06 \pm 0.056^{\mathrm{a}}$ \\
\hline \multirow{2}{*}{ WHC (g/g DW) * } & $\mathrm{CB}$ & $2.31 \pm 0.135$ & $2.78 \pm 0.162^{a}$ \\
\hline & $\mathrm{BB}$ & $2.12 \pm 0.042$ & $2.52 \pm 0.042^{a}$ \\
\hline
\end{tabular}

CB: carp burgers and BB: Barbel burgers. ${ }^{*}$ Results are expressed as means \pm SD $(n=3)$. Control burgers $v s$. Spirulina-fortified burgers: ${ }^{\text {a }} p<0.001$.

Compared to controls, the WHC values of $1 \%$ Spirulina-fortified burgers increased significantly $(p<0.001)$ from 2.31 to 2.78 and 2.12 to 2.52 for carp and barbel formulations, respectively (Table 4$)$. This was probably due to the addition of Spirulina fibers. The great WHC of Spirulina proposes that it could be used as a functional natural ingredient in treatments of food to modify viscosity and texture, reduce dehydration during storage, and minimize energetic value of food products. Furthermore, significant differences $(p<0.001)$ of OHC values were also noted for the two types of Spirulina-fortified burgers (Table 4). These OHC values could be of particular interest, especially for the binding of fat during food industrial production and preservation. This might be attributed to the high water binding and oil binding capacities of the microalgae fibers $[40,43]$. Added to that, the highest values of swelling capacity were obtained by the Spirulina-fortified burgers made from carp $(3.56 \mathrm{~mL} / \mathrm{g})(p<0.001)$ and barbel $(3.43 \mathrm{~mL} / \mathrm{g})(p<0.001)$. The control burgers showed significant inferior values of swelling capacity for carp $(3.13 \mathrm{~mL} / \mathrm{g})$ and barbel $(2.99 \mathrm{~mL} / \mathrm{g})$ (Table 4). Furthermore, the difference between the functional capacities of control and 1\% Spirulina formulations could be explained by the structural properties of each material after the addition of Spirulina fibers. These results are in accordance with previous studies [37,44,45].

\subsection{Microbiological Quality of Fish Burgers}

The burger production process entails a lot of handling of raw food, and therefore hygiene in these food products is a concern for public health given their association with enteric diseases [39]. In our experiment, no mold, Enterobacteriaceae, yeast, coliform bacteria or foodborne pathogens (Salmonella spp., Shigella spp., Listeria monocytogenes, Bacillus cereus and Campylobacter spp.) were detected in any of the control and Spirulina-fortified burgers up to 8 months of storage at $4{ }^{\circ} \mathrm{C}$. The absence of these pathogens indicates that the carp and barbel burgers were both clean and safe even after an extended storage period. These data prove that the processing of the final fish products was executed under perfect hygienic-sanitary conditions.

\subsection{Color Measurement of Burger Samples}

Because of the important influence of food colors on the consumers acceptance, the surface color of carp and barbel burgers have been interpreted into values of color indices $\left(\mathrm{L}^{*}, \mathrm{a}^{*}, \mathrm{~b}^{*}\right)$ that can explain the difference between different treatments using a standard illuminant light source (Table 5). 
Table 5. Color analysis of control burgers and Spirulina-fortified burgers.

\begin{tabular}{cccc}
\hline Color Parameters & \multicolumn{2}{c}{ Fish Burger Types } & \multicolumn{2}{c}{ Burger Formulations } \\
\hline & & Control burger & $1 \%$ Spirulina fish burger \\
\hline \multirow{2}{*}{$\mathrm{L}^{*}$} & $\mathrm{CB}$ & $46.75 \pm 0.335$ & $40.23 \pm 0.961^{\mathrm{a}}$ \\
\cline { 2 - 4 } & $\mathrm{BB}$ & $40.6 \pm 0.07$ & $33.27 \pm 0.530^{\mathrm{a}}$ \\
\hline \multirow{2}{*}{$\mathrm{a}^{*}$} & $\mathrm{CB}$ & $10.65 \pm 0.22$ & $6.23 \pm 0.084^{\mathrm{a}}$ \\
\hline & $\mathrm{BB}$ & $8.18 \pm 0.084$ & $5.2 \pm 0.098^{\mathrm{a}}$ \\
\hline \multirow{2}{*}{$\mathrm{b}^{*}$} & $\mathrm{CB}$ & $11.39 \pm 0.715$ & $7.77 \pm 0.692^{\mathrm{a}}$ \\
\cline { 2 - 4 } & $\mathrm{BB}$ & $18.11 \pm 0.664$ & $5.73 \pm 0.001^{\mathrm{a}}$ \\
\hline
\end{tabular}

CB: carp burgers; BB: barbel burgers; Control burgers vs Spirulina-fortified burgers: ${ }^{\text {a }} p<0.001$.

The $L^{*}$ value measures the brightness of food samples, ranging from 0 (black) to 100 (white) [40]. In cooked burgers, lightness $\left(\mathrm{L}^{*}\right)$ decreased when Spirulina was added. Statistically significant differences $(p<0.001)$ were found between the $1 \%$ Spirulina-fortified samples and the control samples and this is due to the darker colors obtained from Spirulina. We speculate that reducing sugars derived from the hydrolysis of Spirulina polysaccharides during the burgers production may elicit the Maillard reaction to form brown melanoidins [46]. Further, this decrease could be attributed to differences in composition, resulting in different amounts of pigments (chlorophylls and phycocyanin) and water, which is a determining element in the resulting color product [40]. These results indicate that Spirulina has no tendency to lighten the burger's color. Indeed, these results are consistent with those obtained by Senthil et al. [47]. Moreover, carp and barbel burgers fortified with $1 \%$ of Spirulina powder were characterized by significantly low $\mathrm{a}^{*}$ and $\mathrm{b}^{*}$ values $(p<0.001)$, which shows that the yellow color diminished to a greenish color (Table 5). This could be mainly explained by the fact that Spirulina is rich in chlorophylls. These data could be useful in predicting the effect of Spirulina on the conventional color of the products where it will be used. In addition, we can argue that Spirulina pigments could also be useful as natural dyes in fishery products.

\subsection{Antioxidant Properties of Fish Burgers}

Currently, much recent interest has been given to the considerable part of the enriched foods with bioactive substances, usually derived from plants, seaweeds and microalgae thanks to their safety and efficiency in the cure of different human disorders. In fact, the antioxidant activity of microalgae resulted from their abundance in enzymatic and non-enzymatic free radical scavengers. Thus, to estimate the input of Spirulina to the burger antioxidant capacities, two different methods were used: the FRAP and the DPPH free radical-scavenging assays. The results of these methods are summarized in Table 6.

Compared to the control burgers, the addition of Spirulina in burgers increased significantly their antioxidant activities $(p<0.001)$ as well as their chlorophyll $(p<0.001)$, carotenoid $(p<0.001)$ and phycocyanin $(p<0.001)$ contents (Table 6$)$. Furthermore, a positive correlation between antioxidant activity and pigment contents was clearly noticed. At a sample concentration of $10 \mathrm{mg} / \mathrm{ml}$, carp and barbel burgers containing 1\% of Spirulina showed significantly higher DPPH scavenging activities (86.76 and $94.09 \%$, respectively) than control burgers $(56.28$ and $40.09 \%)(p<0.001)$ (Table 6). Furthermore, a comparable trend was also noticed for FRAP. In fact, the ferric reducing activities for unfortified and fortified carp burgers with $1 \%$ of Spirulina, were equal to 0.31 and $0.651(p<0.001)$ respectively, at a sample concentration of $10 \mathrm{mg} / \mathrm{ml}$ (Table 6). Similarly, significant differences $(p<0.001)$ were also found for barbel formulations between 1\% Spirulina-fortified samples and controls (Table 6). The rise in scavenging of free radicals may be attributed to the increase in the carotenoids $[48,49]$, chlorophylls [50], phycocyanin [51,52] and polysaccharides [45] contents, which had an important role in the protection of the body's cells from oxidative stress and many other diseases. In this sense, 
the immulina polysaccharides from Spirulina improve the enzymatic activity of the cell nucleus and synthesis of DNA repair, besides being a beneficial species for the immune system [53,54]. Further, these polysaccharides were showed to have high scavenging activities against superoxide and hydroxyl radicals and moderate reductive power in a concentration-dependent manner $[11,46,55]$. These results also showed that fish burger processing did not have a negative effect on the antioxidant components.

Table 6. Pigments content and antioxidant activities of control and 1\% Spirulina-fortified burgers.

\begin{tabular}{|c|c|c|c|}
\hline \multirow[t]{2}{*}{ Color Parameters } & \multirow[t]{2}{*}{ Fish Burger Types } & \multicolumn{2}{|c|}{ Burger Formulations } \\
\hline & & Control burger & $1 \%$ Spirulina fish burger \\
\hline \multirow{2}{*}{ Chlorophylls (mg/100g DW) } & $\mathrm{CB}$ & 0 & $23.93 \pm 1.675^{\mathrm{a}}$ \\
\hline & BB & 0 & $20.05 \pm 1.97^{\mathrm{a}}$ \\
\hline \multirow{2}{*}{ Phycocyanin (mg/100g DW) } & $\mathrm{CB}$ & 0 & $0.431 \pm 0.033^{a}$ \\
\hline & $\mathrm{BB}$ & 0 & $0.446 \pm 0.199^{a}$ \\
\hline \multirow{2}{*}{ Carotenoids (mg/100g DW) } & $\mathrm{CB}$ & 0 & $12.39 \pm 0.657^{\mathrm{a}}$ \\
\hline & BB & 0 & $14.06 \pm 0.848^{a}$ \\
\hline \multirow{2}{*}{ Scavenging activity (\%) * } & $\mathrm{CB}$ & 56.28 & $86.76^{\mathrm{a}}$ \\
\hline & BB & 40.09 & $94.09^{\mathrm{a}}$ \\
\hline \multirow{2}{*}{ Reducing power* } & $\mathrm{CB}$ & 0.315 & $0.615^{\mathrm{a}}$ \\
\hline & $\mathrm{BB}$ & 0.410 & $0.584^{\mathrm{a}}$ \\
\hline
\end{tabular}

CB: carp burgers; BB: barbel burgers; Control burgers vs. Spirulina-fortified burgers: ${ }^{\text {a }} p<0.001$; ${ }^{*}$ The scavenging activity of DPPH free radicals (\%) and the reducing power (absorbance at $700 \mathrm{~nm}$ ) were determined at a samples concentration of $10 \mathrm{mg} / \mathrm{ml}$.

\section{Conclusions}

The addition of Spirulina seems to be a promising technological alternative for producing fish products, such as burgers made from carp and barbel, because the natural and healthy image of these products, by the consumers, could be improved. Besides its role as a nutritional component, Spirulina serves as suitable source of beneficial natural antioxidant and coloring agents. Furthermore, Spirulina, rich in dietary fibers, plays a central role in the textural maintenance of the final fish products by improving their functional properties (water and oil holding capacities). According to these results, the addition of $1 \%$ of Spirulina in fish burger canning can be recommended since Spirulina is as a natural source of bioactive compounds noting (chlorophylls, carotenoids and phycocyanin). Therefore, the evaluated microalga might be an effective alternative to fortification with synthetic chemical supplements that can cause undesirable effects for consumers. The reasonable selection of Spirulina as a fortifier agent in fish-based products seems to be substantial and it provides food that is both satisfying to the consumer and beneficial to their health.

Author Contributions: M.B., A.B.A., F.H. and M.D. carried out the production of fish burgers and their analysis. B.H. carried out the statistical analysis. M.B., I.F. and S.A. participated in the design of the study. M.B., I.F., M.A.A., P.M. and S.A. conceived the study, and participated in its design and coordination and helped to draft the manuscript. All authors read and approved the final manuscript.

Funding: The study was supported by the Tunisian Ministry of Higher Education and Scientific Research. The funders had no role in study design, data collection and analysis, decision to publish and preparation of the manuscript.

Conflicts of Interest: The authors confirm that they have no conflicts of interest with respect to the study described in this manuscript. 


\section{References}

1. Gökoglu, N.; Yerlikaya, P. Seafood Chilling, Refrigeration and Freezing: Science and Technology, 1st ed.; John Wiley and Sons, Ltd.: Chichester, UK, 2015.

2. Food and Agriculture Organization of the United Nations (FAO). Fisheries and Aquaculture Department, 2015. Available online: http://www.fao.org/fishery/en (accessed on 27 July 2015).

3. Pascoe, S. The sunken billions: The economic justification for fisheries reform. Mar. Resour. Econ. 2012, 27, 193-194. [CrossRef]

4. Mancini, I.; Defant, A.; Mesarič, T.; Potočnik, F.; Batista, U.; Guella, G.; Turk, T.; Sepčić, K. Fatty acid composition of common barbel (Barbus barbus) roe and evaluation of its haemolytic and cytotoxic activities. Toxicon 2011, 57, 1017-1022. [CrossRef] [PubMed]

5. Maiditsch, I.P.; Ladich, F. Effects of temperature on auditory sensitivity in eurythermal fishes: Common Carp Cyprinus carpio (Family Cyprinidae) versus Wels Catfish Silurus glanis (Family Siluridae). PLoS ONE 2014, 9, e108583. [CrossRef]

6. Ljubojevic, D.; Trbovic, D.; Lujic, J.; Bjelic-Cabrilo, O.; Kostic, D.; Novakov, N.; Cirkovic, M. Fatty acid composition of fishes from inland waters. Bulg. J. Agric. Sci. 2013, 19, 62-74.

7. Cedola, A.; Cardinali, A.; Nobile, M.A.D.; Conte, A. Fish burger enriched by olive oil industrial by-Product. Int. J. Food Sci. Nutr. 2017, 5, 837-844. [CrossRef] [PubMed]

8. Carocho, M.; Barreiro, M.F.; Morales, P.; Ferreira, I.C.F.R. Adding molecules to food, pros and cons: A review on synthetic and natural food additives. Compr. Rev. Food Sci. Food Saf. 2014, 13, 377-399. [CrossRef]

9. Ben Amor, F.; Barkallah, M.; Elleuch, F.; Karkouch, N.; Dammak, M.; Baréa, B.; Villeneuve, P.; Abdelkafi, S.; Fendri, I. Cyanobacteria as source of marine bioactive compounds: Molecular specific detection based on $\Delta 9$ desaturase gene. Int. J. Biol. Macromol. 2017, 105, 1440-1445. [CrossRef]

10. Park, W.S.; Kim, H.J.; Li, M.; Lim, D.H.; Kim, J.; Kwak, S.S.; Kang, C.M.; Ferruzzi, M.G.; Ahn, M.J. Two classes of pigments, carotenoids and C-phycocyanin, in Spirulina powder and their antioxidant activities. Molecules 2018, 23, 2065. [CrossRef] [PubMed]

11. Kurd, F.; Samavati, V. Water soluble polysaccharides from Spirulina platensis: Extraction and in vitro anti-cancer activity. Int. J. Biol. Macromol. 2015, 74, 498-506. [CrossRef] [PubMed]

12. Ghaeni, M.; Roomiani, L. Review for application and medicine effects of Spirulina, Spirulina platensis microalgae. JOAAT 2016, 3, 114-117. [CrossRef]

13. Suliburska, J.; Szulińska, M.; Tinkov, A.A.; Bogdański, P. Effect of Spirulina maxima supplementation on calcium, magnesium, iron, and zinc status in obese patients with treated hypertension. Biol. Trace Elem. Res. 2016, 173, 1-6. [CrossRef]

14. Wang, Z.; Zhang, X. Inhibitory effects of small molecular peptides from Spirulina (Arthrospira) platensis on cancer cell growth. Food Funct. 2016, 7, 781-788. [CrossRef] [PubMed]

15. Reichert, M.; Bergmann, S.M.; Hwang, J.; Buchholz, R.; Lindenberger, C. Antiviral activity of exopolysaccharides from Arthrospira platensis against koi herpesvirus. J. Fish Dis. 2017, 40, 1441-1450. [CrossRef] [PubMed]

16. Abd El-Baky, H.H.; El-Baroty, G.S. Characterization and bioactivity of phycocyanin isolated from Spirulina maxima grown under salt stress. Food Funct. 2012, 3, 381-388. [CrossRef]

17. Ben Atitallah, A.; Hentati, F.; Dammak, M.; Hadrich, B.; Fendri, I.; Ayadi, M.-A.; Michaud, P.; Abdelkafi, S.; Barkallah, M. Effect of microalgae incorporation on quality characteristics, functional and antioxidant capacities of ready-to-eat fish burgers made from common carp (Cyprinus carpio). Appl. Sci. 2019, 9, 1830. [CrossRef]

18. Latimer, G.W. Official Methods of Analysis of AOAC International; AOAC International: Gaithersburg, MD, USA, 2016.

19. Bligh, E.G.; Dyer, W.J. A rapid method of total lipid extraction and purification. Can. J. Biochem. Physiol. 1959, 37, 911-9170. [CrossRef]

20. Fendri, I.; Chaari, A.; Dhouib, H.; Jlassi, B.; Abousalham, A.; Carrière, F.; Sayadi, S.; Abdelkafi, S. Isolation, identification and characterization of a new lipolytic Pseudomonas sp., strain AHD-1, from Tunisian soil. Environ. Technol. 2010, 31, 87-95. [CrossRef] [PubMed] 
21. Barkallah, M.; Dammak, M.; Louati, I.; Hentati, F.; Hadrich, B.; Mechichi, T.; Ayadi, M.-A.; Fendri, I.; Attia, H.; Abdelkafi, S. Effect of Spirulina platensis fortification on physicochemical, textural, antioxidant and sensory properties of yogurt during fermentation and storage. LWT Food Sci. Technol. 2017, 84, 323-330. [CrossRef]

22. Lichtenthaler, H.K.; Wellburn, A.R. Determination of total carotenoids and chlorophylls A and B or leaf in dissolved solvents. Biochem. Soc. Trans. 1985, 11, 591-592. [CrossRef]

23. Kumar, P.; Ramakritinan, C.M.; Kumaraguru, A.K. Solvent extraction and spectrophotometric determination of pigments of some algal species from the shore of puthumadam, southeast coast of India. Int. J. Oceans Oceanogr. 2010, 4, 29-34.

24. Bennett, A.; Bogorad, L. Complementary chromatic adaptation in a filamentous blue-green alga. J. Cell Biol. 1973, 58, 419-435. [CrossRef] [PubMed]

25. Kuniak, L.; Marchessault, R.H. Study of the crosslinking reaction between epichlorohydrin and starch. Starch Starke 1972, 24, 110-116. [CrossRef]

26. Okezie, B.O.; Bello, A.B. Physicochemical and functional properties of winged bean flour and isolate compared with soy isolate. J. Food Sci. 1988, 53, 450-454. [CrossRef]

27. Wong, K.H.; Cheung, P.C.K. Nutritional evaluation of some subtropical red and green seaweeds. Part I-Proximate composition, amino acid profiles and some physicochemical properties. Food Chem. 2000, 71, 475-482. [CrossRef]

28. Bourne, M.C. Texture profile analysis. Food Technol. 1978, 32, 62-66.

29. Bersuder, P.; Hole, M.; Smith, G. Antioxidants from a heated histidine glucose model system I: Investigation of the antioxidant role of histidine and isolation of antioxidants by high performance liquid chromatography. J. Am. Oil Chem. Soc. 1998, 75, 181-187. [CrossRef]

30. Yildirim, A.; Mavi, A.; Kara, A.A. Determination of antioxidant and antimicrobial activities of Rumex crispus L. Extracts. J. Agric. Food Chem. 2001, 49, 4083-4089. [CrossRef]

31. American Public Health Association (APHA). Compendium of Methods for the Microbiological Examination of Foods, 4th ed.; Downes, F.P., Ito, K., Eds.; American Public Health Association (APHA): Washington, DC, USA, 2001.

32. Abdelkafi, S.; Labat, M.; Gam, Z.B.A.; Lorquin, J.; Sayadi, S. Optimized conditions for the synthesis of vanillic acid under hypersaline conditions by Halomonas elongata DSM 2581Tresting cells. World J. Microbiol. Biotechnol. 2008, 24, 675-680. [CrossRef]

33. Shimamatsu, H. Mass production of Spirulina, an edible microalga. Hydrobiologia 2004, 512, 39-44. [CrossRef]

34. Dammak, M.; Hadrich, B.; Miladi, R.; Barkallah, M.; Hentati, F.; Hachicha, R.; Laroche, C.; Michaud, P.; Fendri, I.; Abdelkafi, S. Effects of nutritional conditions on growth and biochemical composition of Tetraselmis sp. Lipids Health Dis. 2017, 16, 41. [CrossRef]

35. Selani, M.M.; Shirado, G.A.N.; Margiotta, G.B.; Saldaña, E.; Spada, F.P.; Piedade, S.M.S.; Contreras-Castillo, C.J.; Canniatti-Brazaca, S.G. Effects of pineapple byproduct and canola oil as fat replacers on physicochemical and sensory qualities of low-fat beef burger. Meat Sci. 2016, 112, 69-76. [CrossRef]

36. Cofrades, S.; López-López, I.; Solas, M.; Bravo, L.; Jiménez-Colmenero, F. Influence of different types and proportions of added edible seaweeds on characteristics of different types and proportions of added edible seaweeds on characteristics of low-salt gel/emulsion meat systems. Meat Sci. 2008, 79, 767-776. [CrossRef] [PubMed]

37. Fernandez-Martin, F.; Lopez-Lopez, I.; Cofrades, S.; Colmenero, F.J. Influence of adding Sea Spaghetti seaweed and replacing the animal fat with olive oil or a konjac gel on pork meat batter gelation. Potential protein/alginate association. Meat Sci. 2009, 83, 209-217. [CrossRef]

38. Dolea, D.; Rizo, A.; Fuentes, A.; Barat, J.M.; Fernandez-Segovia, I. Effect of thyme and oregano essential oils on the shelf life of salmon and seaweed burgers. Food Sci. Technol. Int. 2018, 24, 394-403. [CrossRef]

39. López-Vargas, J.H.; Fernández-López, J.; Pérez-Álvarez, J.Á.; Viuda-Martos, M. Quality characteristics of pork burger added with albedo-fiber powder obtained from yellow passion fruit (Passiflora edulis var. flavicarpa) co-products. Meat Sci. 2014, 97, 270-276. [CrossRef] [PubMed]

40. Huber, E.; Francio, D.L.; Biasi, V.; Mezzomo, N.; Ferreira, S.R.S. Characterization of vegetable fiber and its use in chicken burger formulation. J. Food Sci. Technol. 2016, 53, 3043-3052. [CrossRef] [PubMed]

41. Muñoz, L.M.J.; Díaz, I.S.; Rohner, C.S.; Ramirez, G.C.; Ambrosio, A.F. Effectiveness of high power ultrasound for surimi-based preparation of lionfish (Pterois volitans) patties by textural, sensory and shape preference. J. Culin. Sci. Technol. 2017, 17, 89-102. [CrossRef] 
42. Kumarathunge, N.C.; Jayasinghe, J.M.P.; Abeyrathne, E.D.N.S. Development of sea lettuce (Ulva lactuca) and Catla (Catla catla) incorporated protein and fiber rich fish burger. Int. J. Res. Agric. Sci. 2016, 4, 2348-3997.

43. Roohinejad, S.; Koubaa, M.; Barba, F.J.; Saljoughian, S.; Amid, M.; Greiner, R. Application of seaweeds to develop new food products with enhanced shelf-life, quality and health-related beneficial properties. Food Res. Int. 2016, 99, 1066-1083. [CrossRef] [PubMed]

44. López-López, I.; Cofrades, S.; Cañeque, V.; Díaz, M.T.; López, O.; Jiménez-Colmenero, F. Effect of cooking on the chemical composition of low-salt, low-fat Wakame/olive oil added beef patties with special reference to fatty acid content. Meat Sci. 2011, 89, 27-34. [CrossRef]

45. Cox, S.; Abu-Ghannam, N. Enhancement of the phytochemical and fibre content of beef patties with Himanthalia elongata seaweed. Int. J. Food Sci. Technol. 2013, 48, 2239-2249.

46. Luo, A.; Feng, J.; Hu, B.; Lv, J.; Chen, C.O.; Xie, S. Polysaccharides in Spirulina platensis improve antioxidant capacity of chinese-style sausage. J. Food Sci. 2017, 82, 2591-2597. [CrossRef] [PubMed]

47. Senthil, M.A.; Mamatha, B.; Mahadevaswamy, M. Effect of using seaweed (Eucheuma) powder on the quality of fish cutlet. Int. J. Food Sci. Nutr. 2005, 56, 327-335. [CrossRef] [PubMed]

48. Goiris, K.; Muylaert, K.; Fraeye, I.; Foubert, I.; De Brabanter, J.; De Cooman, L. Antioxidant potential of microalgae in relation to their phenolic and carotenoid content. J. Appl. Phycol. 2012, 24, 1477-1486. [CrossRef]

49. Bezerra, P.Q.M.; Matos, M.F.R.; Ramos, I.G.; Magalhães-Guedes, K.T.; Druzian, J.I.; Costa, J.A.V.; Nunes, I.L. Innovative functional nanodispersion: Combination of carotenoid from Spirulina and yellow passion fruit albedo. Food Chem. 2019, 258, 397-405. [CrossRef]

50. Ismaiel, M.M.; El-Ayouty, Y.M.; Piercey-Normore, M. Role of $\mathrm{pH}$ on antioxidants production by Spirulina (Arthrospira) platensis. Braz. J. Microbiol. 2016, 47, 298-304. [CrossRef]

51. Anbarasan, V.; Kumar, V.K.; Kumar, P.S.; Venkatachalam, T. In vitro evaluation of antioxidant activity of blue green algae S. platensis. Int. J. Pharm. Sci. Res. 2011, 2, 2616-2618.

52. Ben Atitallah, A.; Barkallah, M.; Hentati, F.; Dammak, M.; Hlima, H.B.; Fendri, I.; Attia, H.; Michaud, P.; Abdelkafi, S. Physicochemical, textural, antioxidant and sensory characteristics of microalgae-fortified canned fish burgers prepared from minced flesh of common barbel (Barbus barbus). Food Biosci. 2019, 30, 100417. [CrossRef]

53. Chaiklahan, R.; Chirasuwan, N.; Triratana, P.; Loha, V.; Tia, S.; Bunnag, B. Polysaccharide extraction from Spirulina sp. and its antioxidant capacity. Int. J. Biol. Macromol. 2013, 58, 73-78. [CrossRef]

54. Pugh, N.; Ross, S.A.; ElSohly, H.N.; Elsohly, M.A.; Pasco, D.S. Isolation of three high molecular weight polysaccharide preparations with potent immunostimulatory activity from Spirulina platensis, Aphanizomenon flos-aquae and Chlorella pyrenoidosa. Planta Med. 2001, 67, 737-742. [CrossRef]

55. Jónsdóttir, R.; Geirsdóttir, M.; Hamaguchi, P.Y.; Jamnik, P.; Kristinsson, H.G.; Undeland, I. The ability of in vitro antioxidant assays to predict the efficiency of a cod protein hydrolysate and brown seaweed extract to prevent oxidation in marine food model systems. J. Sci. Food Agric. 2015, 96, 2125-2135. [CrossRef] [PubMed]

(C) 2019 by the authors. Licensee MDPI, Basel, Switzerland. This article is an open access article distributed under the terms and conditions of the Creative Commons Attribution (CC BY) license (http://creativecommons.org/licenses/by/4.0/). 